\title{
PENERAPAN MODEL PEMBELAJARAN THINK-TALK-WRITE UNTUK MENINGKATKAN AKTIVITAS DAN PRESTASI BELAJAR MATEMATIS SISWA MTS DARUL QURAN BENGKEL
}

\author{
Sowanto $^{* 1}$, Harry Soeprianto ${ }^{2}$, Hapipi $^{2}$ \\ ${ }^{1}$ Program Studi Pendidikan Matematika, STKIP Bima \\ ${ }^{2}$ Program Studi Pendidikan Matematika, Universitas Mataram \\ *Email korespondensi: sowantos@gmail.com
}

\begin{abstract}
ABSTRAK
Penelitian tindakan kelas ini dilatarbelakangi oleh rendahnya aktivitas dan prestasi belajar matematika siswa kelas VIIIB MTs. Darul Quran Bengkel. Hal ini menjadikan aktivitas belajar siswa berkurang dan berakibat pada rendahnya prestasi belajar matematika siswa. Untuk mengatasi permasalahan ini, guru perlu menerapkan suatu strategi pembelajaran yang mampu menekankan keterampilan proses dalam upaya meningkatkan peran aktif dan prestasi belajar siswa di kelas, salah satu alternatifnya dengan menerapkan pembelajaran Think-Talk-Write (TTW). Adapun tujuan dari penelitian ini yaitu untuk meningkatkan aktivitas dan prestasi belajar siswa pada materi pokok lingkaran di kelas VIIIB MTs. Darul Quran Bengkel. Penelitian ini dilaksanakan dalam dua siklus dengan masing-masing siklusnya terdiri dari 3 kali pertemuan. Setiap siklus terdiri dari tahap perencanaan, pelaksanaan tindakan, observasi, evaluasi, dan refleksi. Data prestasi belajar siswa diperoleh melalui evaluasi hasil belajar tiap akhir siklus, sedangkan data aktivitas guru dan aktivitas belajar siswa diperoleh melalui lembar observasi. Hasil penelitian menunjukkan terjadi peningkatan rata-rata skor aktivitas dan prestasi belajar siswa dari siklus I ke siklus II. Perolehan rata-rata skor aktivitas siswa pada siklus I dan siklus II berturut-turut adalah 12,5 yang berkategori aktif dan 14,67 yang berkategori sangat aktif. Kemudian nilai rata-rata kelas siswa untuk siklus I dan siklus II berturutturut adalah 66,6 dengan ketuntasan belajar 75\% dan 73,8 dengan ketuntasan belajar 78,38 \%. Dengan memperhatikan hasil serta indikator keberhasilan yang tercapai, maka dapat disimpulkan bahwa penerapan strategi pembelajaran Think-Talk-Write (TTW) dapat meningkatkan aktivitas dan prestasi belajar siswa pada materi pokok Lingkaran di Kelas VIIIB MTs. Darul Quran Bengkel.
\end{abstract}

Kata kunci : Think-Talk-Write, aktivitas belajar matematis, prestasi belajar matematis

\begin{abstract}
This classroom action research was motivated by the lack of activity and mathematics learning achievement of class VIIIB students of MTs. Darul Quran Bengkel. This makes student learning activities decrease and results in low mathematics learning achievement of students. To overcome this problem, the teacher needs to apply a learning strategy that is able to emphasize process skills in an effort to increase the active role and student achievement in the classroom, one of the alternatives is to apply Think-Talk-Write (TTW) learning. The purpose of this study is to increase the activity and student learning achievement on the subject matter of the circle in class VIIIB MTs. Darul Quran Bengkel. This research was conducted in two cycles with each cycle consisting of 3 meetings. Each cycle consists of planning, action, observation, evaluation, and reflection. Data on student learning achievement is obtained through the evaluation of learning outcomes at the end of each cycle, while
\end{abstract}


data on teacher activity and student learning activities are obtained through observation sheets. The results showed an increase in the average score of activities and student learning achievements from cycle I to cycle II. The average score of student activity in the first cycle and the second cycle was 12.5 active categories and 14.67 were very active. Then the average grade of students for the cycle I and cycle II were 66.6 with learning completeness $75 \%$ and 73.8 with learning completeness $78.38 \%$. By paying attention to the results and indicators of success achieved, it can be concluded that the application of the Think-Talk-Write (TTW) learning strategy can improve student activity and learning achievement in the subject matter of Circles in Class VIIIB MTs. Darul Quran Bengkel.

Keywords: Think-Talk-Write, mathematical learning activities, mathematical learning achievement

\section{PENDAHULUAN}

Pada proses pembelajaran matematika, guru memiliki peranan dan tanggung jawab yang sangat besar dalam pencapaian tujuan pembelajaran. Guru dituntut untuk memiliki kemampuan merancang dan menggunakan strategi pembelajaran yang dapat menumbuhkan cara berfikir siswa agar menjadi lebih kritis dan kreatif guna membuat proses belajar yang berlangsung menjadi tidak monoton. Lebih lanjut Slameto dalam Sowanto (2018) mengemukakan bahwa berhasil tidaknya suatu kegiatan pembelajaran bergantung pada kemampuan dan kreativitas guru menciptakan proses belajar yang sedemikian rupa sehingga dapat merangsang siswa untuk belajar secara aktif.

Berdasarkan hasil observasi di MTs. Darul Quran Bengkel, diperoleh bahwa pada proses pembelajaran matematika di kelas VIII MTs. Darul Quran Bengkel selama ini umumnya guru menggunakan metode konvensional dimana pada proses pembelajaran guru mendominasi dalam menyampaikan materi melalui metode ceramah sedangkan siswa cenderung hanya mendengar, mencatat dan mengerjakan soal yang diberikan oleh guru. Pembelajaran seperti ini akan mematikan kreativitas siswa sehingga siswa cenderung pasif dalam proses pembelajaran karena siswa masih sangat tergantung pada penjelasan yang diberikan oleh guru dan siswa jarang berdiskusi dengan siswa lainnya dalam menghadapi masalah matematika, bahkan hampir tidak berani mengajukan pertanyaan jika ada ketidakjelasan materi yang disampaikan guru. Hal ini akan menjadikan aktivitas belajar siswa berkurang dan berakibat dapat menurunkan kemampuan berpikir siswa. Hal ini sesuai dengan yang dinyatakan Sowanto dan Kusumah (2018) bahwa "to improving the cognitive aspects of students, increasing the affective aspect of the psychological aspects associated with the attitude of students as well as supporting success in the process of learning mathematics is a must”.

Permasalahan-permasalahan di atas pada akhirnya akan bermuara pada rendahnya prestasi belajar matematika siswa. Kelas VIIIB merupakan kelas dengan nilai rata-rata kelas 
terendah yang terlihat dari lebih rendahnya nilai rata-rata matematika kelas VIIIB berdasarkan arsip dari guru seperti tabel di bawah ini.

Tabel 1. Data Prestasi Belajar Matematika Siswa Kelas VIII Semester I MTs. Darul Quran Bengkel

\begin{tabular}{cccc}
\hline No & Kelas & Jumlah Siswa & Rata-rata nilai kelas \\
\hline 1 & VIIIA & 38 & 68,67 \\
2 & VIIIB & 38 & 61,18 \\
3 & VIIIC & 39 & 64,70 \\
\hline
\end{tabular}

Berdasarkan hasil wawancara dengan guru mata pelajaran matematika di kelas VIIIB, diperoleh bahwa dari sekian banyak materi pokok di kelas VIII, lingkaran termasuk salah satu materi yang dianggap sulit oleh sebagian besar siswa. Ditinjau dari segi struktur materi, konsep, dan prinsip-prinsipnya, pada dasarnya materi lingkaran telah akrab dikenal oleh siswa dalam kehidupan sehari-hari. Oleh karena itu, siswa telah memililki pengetahuan awal atau prakonsep berdasarkan pengalaman yang telah diperolehnya tentang lingkaran, namun kenyataannya materi lingkaran termasuk salah satu materi yang dianggap sulit oleh sebagian besar siswa.

Jika disesuaikan dengan permasalahan-permasalahan yang dihadapi oleh siswa kelas VIIIB MTs. Darul Quran Bengkel, perlu diterapkan suatu strategi pembelajaran yang mampu menekankan keterampilan proses dalam upaya peningkatan peran aktif dan prestasi belajar siswa di kelas salah satu alternatifnya dengan menerapkan pembelajaran dengan strategi Think-Talk-Write. Strategi Think-Talk-Write yang diterapkan melalui belajar dalam kelompok kecil merupakan salah satu alternatif strategi pembelajaran yang dapat digunakan. Menurut Ahmadi dan Prasetya (1997), belajar dan bekerja dalam kelompok merupakan bentuk kegiatan belajar aktif yang mampu menumbuhkembangkan keterampilan sosial siswa. Lebih lanjut menurut Duren dan Cherrington dalam Helmaheri (2004) terdapat perbedaan yang signifikan dalam ingatan jangka panjang siswa (student's long term retention) antara siswa yang belajarnya mengerjakan latihan secara kelompok dibandingkan dengan siswa yang belajarnya secara sendiri. Oleh karenanya, dalam penelitian ini pada kegiatan pemecahan masalah diterapkan melalui belajar dalam kelompok-kelompok kecil beranggotakan 4 hingga 5 orang untuk tiap kelompoknya.

Melalui strategi Think-Talk-Write, pada tahap think (berpikir) siswa membaca teks berupa bahan bacaan maupun soal. Dalam tahap ini siswa secara individu memikirkan 
kemungkinan jawaban (strategi penyelesaian), membuat catatan kecil tentang ide-ide yang terdapat pada bacaan, dan hal-hal yang tidak dipahaminya sesuai dengan bahasanya sendiri. Pada tahap talk (berbicara atau diskusi) memberikan kesempatan kepada siswa untuk membicarakan tentang penyelidikannya pada tahap berpikir. Pada tahap ini siswa merefleksikan, menyusun, serta menguji (negosiasi, sharing) ide-ide dalam kegiatan diskusi kelompok. Kemajuan komunikasi antar siswa dalam kelompoknya akan terlihat pada dialognya dalam berdiskusi ataupun refleksi mereka sendiri yang diungkapkannya kepada orang lain. Pada tahap write (menulis) siswa menuliskan ide-ide yang diperolehnya dari kegiatan tahap pertama dan kedua. Tulisan ini terdiri atas landasan konsep yang digunakan, keterkaitan dengan materi sebelumnya, strategi penyelesaian, dan solusi yang diperolehnya.

Strategi pembelajaran ini dipilih, karena melalui tahap berpikir memberikan kesempatan bagi siswa untuk mengembangkan keterampilan berpikirnya dalam memecahkan masalah. Nasution (2010) berkata, "dalam semua proses pemecahan masalah, yang paling penting dan paling sukar ialah langkah pertama yakni mencari, mengidentifikasi, merumuskan dan menjelaskan masalah". Oleh karena itu, tahap berpikir merupakan basis bagi siswa untuk memahami adanya masalah. Membangun interaksi siswa yang merupakan pengembangan kemampuan sosial seperti berkomunikasi dan berpendapat dilakukan pada tahap berbicara. Pada tahap menulis siswa belajar menuliskan bahasa matematika dengan tepat yang berupa lambang matematis, bilangan, gambar, tabel matematika.

\section{METODE PENELITIAN}

Jenis penelitian ini adalah penelitian tindakan kelas (Classroom Action Research) yang merupakan suatu pencermatan terhadap kegiatan belajar berupa tindakan, yang sengaja dimunculkan dan terjadi dalam sebuah kelas secara bersama (Arikunto, 2011).

Penelitian tindakan kelas ini direncanakan dilaksanakan dalam 2 siklus. Setiap siklusnya meliputi lima tahap kegiatan yaitu pertama tahap perencanaan (planning) meliputi tersusunnya instrumen pembelajaran, kedua tahap pelaksanaan tindakan (acting) yaitu dengan melaksanakan kegiatan belajar mengajar di kelas sesuai dengan rencana yang telah disusun berdasarkan skenario pembelajaran yang telah dibuat, ketiga yaitu tahap observasi (observing) untuk mengamati aktivitas guru dan siswa selama proses pembelajaran berlangsung, keempat tahap evaluasi (evaluation) hasil belajar siswa pada setiap akhir sikulus dan kelima yaitu tahap refleksi (reflecting) dilakukan pada akhir siklus dengan menganalisis hasil tes dan observasi. 
Adapun untuk setiap siklus terdiri atas dua kali pertemuan untuk kegiatan belajar mengajar dan satu kali pertemuan untuk evaluasi.

\section{HASIL DAN PEMBAHASAN}

Berdasarkan hasil analisis jawaban dari soal geometri yang diselesaikan oleh 9 subyek diperoleh karakteristik keterampilan geometri siswa dalam memecahkan masalah geometri berdasarkan tingkat berpikir Van Hiele untuk tingkat 0 (visualisasi), tingkat 1 (analisis), dan tingkat 2 (deduksi informal). Dimana untuk masing-masing tingkat berpikir, data yang dianalisis berasal dari tiga subyek yang mengkategorikan data ke dalam lima keterampilan geometri, yaitu keterampilan visual, keterampilan verbal, keterampilan menggambar, keterampilan logika, dan keterampilan terapan.

Penelitian tindakan kelas ini dilaksanakan sebagai upaya meningkatkan aktivitas dan prestasi belajar siswa pada materi pokok lingkaran di kelas VIIIB MTs. Darul Quran Bengkel dengan menerapkan strategi Think-Talk-Write. Penelitian ini dilakukan dalam dua siklus dengan ringkasan hasil analisis observasi aktivitas dan prestasi belajar siswa siklus I dan siklus II dapat dilihat pada tabel berikut:

Tabel 2. Hasil Observasi Aktivitas dan Hasil Evaluasi Belajar Siswa dalam Dua Siklus

\begin{tabular}{ccccccc}
\hline & \multicolumn{2}{c}{ Aktivitas Belajar } & \multicolumn{2}{c}{ Prestasi Belajar Siswa } & \multirow{2}{*}{$\begin{array}{c}\text { Ketuntasan } \\
\text { Siklus }\end{array}$} \\
\cline { 2 - 6 } & \multicolumn{2}{c}{ Siswajar } \\
& $\begin{array}{c}\text { Rata-rata } \\
\text { Skor }\end{array}$ & Kategori & $\begin{array}{c}\text { Nilai } \\
\text { Terendah }\end{array}$ & $\begin{array}{c}\text { Nilai } \\
\text { Tertinggi }\end{array}$ & $\begin{array}{c}\text { Nilai } \\
\text { Rata-rata }\end{array}$ & Belajarn \\
\hline I & 12,5 & Aktif & 37 & 96 & 66,6 & $75 \%$ \\
II & 14,67 & $\begin{array}{c}\text { Sangat } \\
\text { Aktif }\end{array}$ & 40 & 100 & 73,8 & $78,38 \%$ \\
\hline
\end{tabular}

Berdasarkan tabel 2 di atas, dapat kita lihat bahwa peningkatan rata-rata skor aktivitas belajar siswa terjadi pada setiap siklus, dan juga sejalan dengan peningkatan prestasi belajar siswa kelas VIIIB berupa nilai rata-rata kelas.

Pada siklus I rata-rata skor aktivitas siswa yaitu 12,5 yang berkategori aktif dengan skor aktivitas siswa pada setiap pertemuan mengalami peningkatan yaitu dari 11,67 yang berkategori aktif pada pertemuan pertama menjadi 13,32 yang juga berkategori aktif pada pertemuan kedua. Namun pada siklus I masih terlihat kekurangan pada proses pembelajaran yang dipengaruhi oleh faktor guru dan siswa yang perlu diperbaiki pada siklus II. 
Adapun kekurangan yang terjadi pada siklus I diantaranya adalah kerjasama siswa dalam diskusi dengan sesama anggota kelompoknya dalam menyelesaikan tugas pada LKK yang diberikan terlihat masih kurang, terlihat juga siswa masih malu menanggapi maupun menyanggah hasil diskusi kelompok lain ketika presentasi kelompok, kemudian ketika pemantapan konsep siswa yang pintar masih mendominasi dalam mengerjakan soal latihan. Di samping itu, guru belum mengaitkan materi yang akan dibahas dengan materi sebelumnya, guru juga perlu memperhatikan alokasi waktu untuk tiap tahap pembelajaran, kemudian pada pertemuan kedua guru kurang memantau kegiatan siswa yang pasif dalam kelompoknya masing-masing.

Untuk pencapaian hasil yang lebih optimal dan lebih baik, pada proses pembelajaran siklus II guru melakukan perbaikan-perbaikan dan penyempurnaan dari kekurangankekurangan yang terdapat pada siklus I yaitu guru berusaha mengaitkan materi pada pertemuan sebelumnya dengan materi yang akan dibahas, kemudian agar kegiatan diskusi dapat maksimal alokasi waktu untuk kegiatan diskusi pada tahap berbikir dan berbicara, serta ketika siswa menyelesaikan soal latihan akan lebih diperbanyak, selanjutnya guru juga membagikan materi dan LKK secara merata kepada semua anggota kelompok sehingga tidak ada lagi siswa yang hanya diam atau pasif ketika kegiatan diskusi kelompok.

Agar tidak hanya siswa yang pandai yang mendominasi kegiatan diskusi, pada pembelajaran siklus II guru meminta perwakilan dari tiap-tiap kelompok yang belum pernah menjadi pembicara untuk menyampaikan kesimpulan dari hasil diskusi kelompoknya, kemudian untuk pemantapan konsep ketika mengerjakan soal latihan guru menunjuk siswa yang belum pernah menuliskan jawaban soal latihan dari tiap-tiap kelompok untuk menuliskan jawabannya di papan tulis.

Tindakan perbaikan ini sejalan dengan yang diungkapkan oleh Sardiman (2011) bahwa tugas pendidik adalah membimbing dan menyediakan kondisi agar anak didik dapat mengembangkan bakat dan potensinya. Dalam hal ini, anaklah yang beraktivitas, berbuat dan harus aktif sendiri dalam proses belajar seperti bertanya, mengajukan pendapat, mendiskusikan materi ajar, dan mengerjakan tugas-tugas. Sehingga hasilnya terjadi peningkatan perolehan rata-rata skor aktivitas siswa yaitu dari 12,5 yang berkategori aktif pada siklus I menjadi 14,67 yang berkategori sangat aktif pada siklus II. 
Selanjutnya tindakan perbaikan ini juga sesuai dengan yang diungkapkan Slameto (2010) bahwa dengan partisipasi aktif siswa, pengetahuan mereka akan berkembang dengan lebih baik yang pada akhirnya diharapkan mampu meningkatkan prestasi belajar siswa itu sendiri. Sehingga hasilnya nilai rata-rata kelas siswa yang semula adalah 66,6 pada siklus I, setelah dilakukan perbaikan-perbaikan dan penyempurnaan mengalami peningkatan menjadi 73,8 pada siklus II, seiring dengan itu juga ketuntasan belajar siswa mengalami peningkatan yaitu dari $75 \%$ pada siklus I menjadi $78,38 \%$ pada siklus II.

Terpenuhinya indikator keberhasilan penelitian yang berupa peningkatan nilai ratarata kelas maupun rata-rata skor aktivitas belajar siswa untuk setiap siklus, maka penelitian dicukupkan sampai siklus II.

Dari hasil penelitian di atas menunjukkan bahwa strategi Think-Talk-Write yang diterapkan telah mampu menumbuhkan suasana pembelajaran yang membuat siswa melakukan aktivitas-aktivitas dalam belajar dengan baik yang tentunya akan berpengaruh baik pula terhadap pencapaian prestasi belajar siswa itu sendiri. Karena melalui belajar dalam kelompok, siswa dapat melatih interaksi sosialnya dengan belajar bekerja sama dengan teman satu kelompoknya dalam menyelesaikan tugas berupa penemuan-penemuan konsep pada LKK. Hal ini sesuai yang kemukakan oleh Duren dan Cherrington (dalam Helmaheri, 2004) bahwa terdapat perbedaan yang signifikan dalam ingatan jangka panjang siswa (student's long term retention) antara siswa yang belajarnya mengerjakan latihan secara kelompok dibandingkan dengan siswa yang belajarnya secara sendiri.

Dengan demikian sesuai dengan hasil yang diperoleh pada penelitian ini, baik dari segi aktivitas belajar maupun hasil evaluasi belajar dari siklus I dan siklus II menunjukkan bahwa tahapan-tahapan pembelajaran pada strategi Think-Talk-Write mampu memberikan kontribusi terhadap peningkatan aktivitas dan prestasi belajar siswa pada materi pokok Lingkaran di kelas VIIIB MTs. Darul Quran Bengkel.

\section{KESIMPULAN}

Berdasarkan hasil penelitian dan pembahasan diperoleh simpulan bahwa penerapan strategi Think-Talk-Write dapat meningkatkan aktivitas dan prestasi belajar siswa pada materi pokok lingkaran di kelas VIIIB MTs. Darul Quran Bengkel tahun. Hal ini terlihat dari peningkatan skor aktivitas siswa yaitu dari 12, 5 yang berkategori aktif pada siklus 1 menjadi 
14,67 yang berkategori sangat aktif pada siklus II, dan perolehan nilai rata-rata kelas siswa yang meningkat yaitu dari 66,6 pada siklus 1 menjadi 73,8 pada siklus II.

Melalui penerapan strategi Think-Talk-Write setiap tahapnya memberikan kesempatan kepada siswa untuk mengeksplorasi kemampuan matematisnya seperti pada tahap think, siswa diberikan kesempatan mencari dan memikirkan alternatif penyelesaian dari masalah melalui membaca bahan bacaan/materi dan LKK secara individu dalam kelompok serta melakukan percobaan secara bersama-sama, Pada tahap talk, setiap siswa diberikan kesempatan untuk membicarakan penyelidikannya pada tahap berpikir, dengan menyampaikan informasi berupa hal-hal yang dipahami maupun tidak dipahaminya dari membaca bahan bacaan/materi dan LKK serta hasil melakukan percobaan yang diperolehnya yang selanjutnya dibahas dan diskusikan dengan anggota kelompoknya yang lain. Sehingga diharapkan seluruh siswa dapat saling aktif mencari tahu, serta pada tahap iwrite, siswa diberikan kesempatan mengkonstruksi konsep maupun rumus-rumus pada sub materi pokok Lingkaran dengan menjawab pertanyaan pada lembar kerja kelompok yang merupakan hasil diskusi.

\section{REKOMENDASI}

Rekomendasi dari penelitian ini adalah peneliti merekomendasikan bagi guru Matematika maupun pendidik lainnya, sekirannya menerapkan strategi Think-Talk-Write pada materi pokok Lingkaran agar lebih memperhatikan dan memaksimalkan langkah-langkah pembelajarannya sehingga proses pembelajaran dapat lebih optimal. Serta lebih persuasif dan kreatif dalam mengajak siswa yang pasif agar dapat melibatkan diri secara aktif dalam proses diskusi maupun dalam mengerjakan soal latihan.

\section{UCAPAN TERIMAKASIH}

Penelitian ini dapat terlaksana dengan baik karena ada pihak-pihak yang telah membantu. Terimakasih kepada kepala sekolah MTs Darul Quran Bengkel, Guru Matematika kelas VIIIB dan siswa-siswa kelas VIIIB Darul Quran Bengkel.

\section{REFERENSI}

Ahmadi, A. dan Prasetya, J.T. (1997). Strategi Belajar Mengajar Untuk Fakultas Tarbiyah Komponen MKDK. Bandung: Pustaka Setia.

Arikunto, S. (2011). Penelitian Tindakan Kelas. Jakarta: Bumi Aksara. 
Helmaheri. (2004). Mengembangkan Kemampuan Komunikasi dan Pemecahan Masalah Matematik Siswa SLTP melalui Strategi Think-Talk-Write dalam Kelompok Kecil (Studi Eksperimen di SMPN 3 Teluk Kuantan Kabupaten Kuantan Singingi Propinsi Riau). (Skripsi). FPMIPA Universitas Pendidikan Indonesia, Bandung.

Nasution. (2010). Kurikulum dan Pengajaran. Bandung: Bumi Aksara.

Sardiman, A.M. (2011). Interaksi dan Motivasi Belajar Mengajar. Jakarta: Rajawali Pers.

Slameto. (2010). Belajar dan Faktor-Faktor yang Mempengaruhinya. Jakarta: Rineka Cipta.

Sowanto. (2018). Enhancing Students' Mathematical Representation and Self-Efficacy Through Situation-Based Learning Assisted by Geometer's Sketchpad Program. IOP Conf. Series: Journal of Physics: Conf. Series 1013 (2018) 012107. Tersedia pada doi :10.1088/1742$6596 / 1013 / 1 / 012107$

Sowanto dan Kusumah, Y.S. (2018). Bahan Ajar pada Materi Garis Singgung Lingkaran dengan Pendekatan Saintifik untuk Siswa SMP. KALAMATIKA Jurnal Pendidikan Matematika, 3(1), 63-80. Tersedia hada htt//kalamatika.matematikauhamka.com/index.php/kmk/article/view/127 